
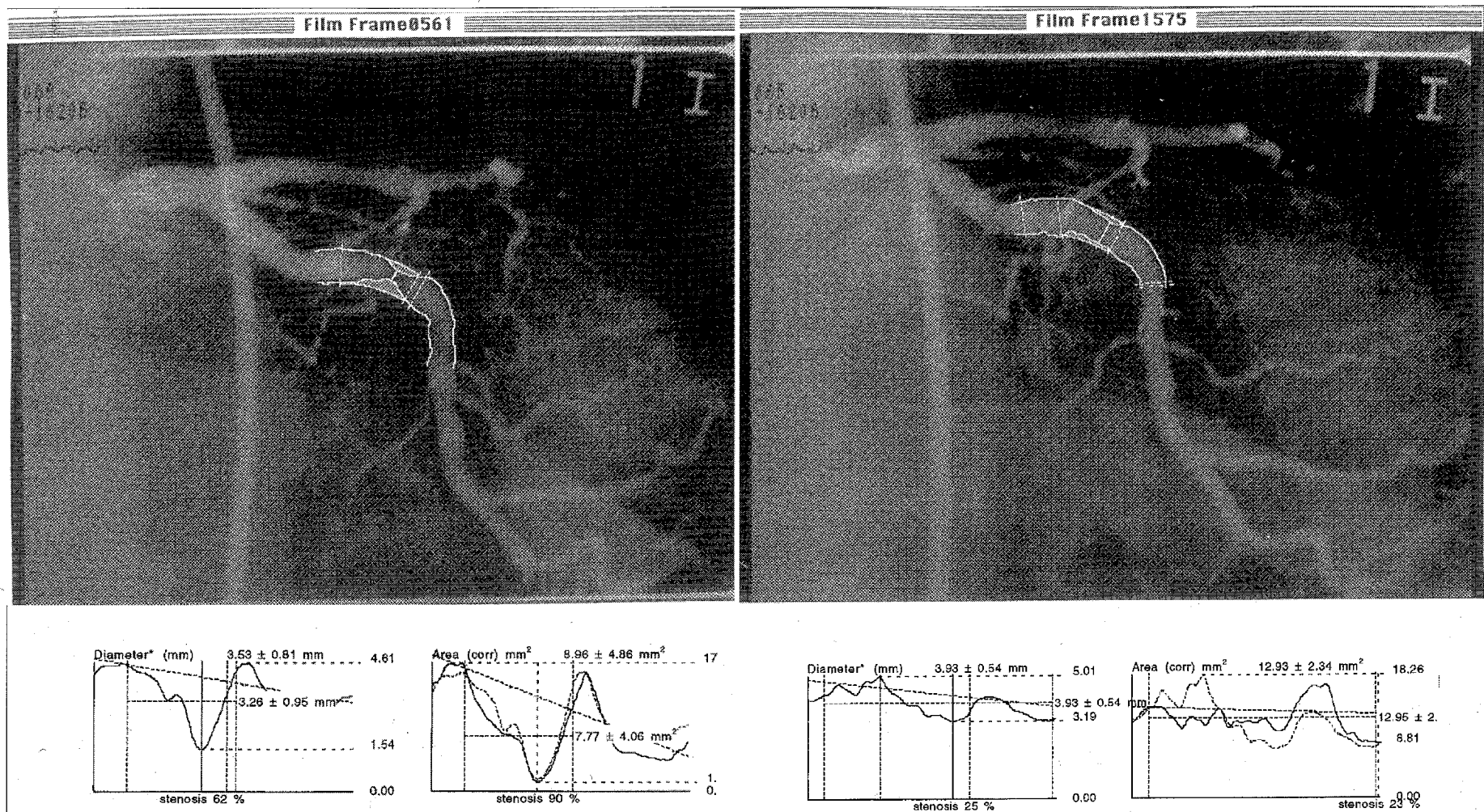

Length user defined segment : $11.53 \mathrm{~mm}$, Voiume : $81.87 \mathrm{~mm}^{3}$
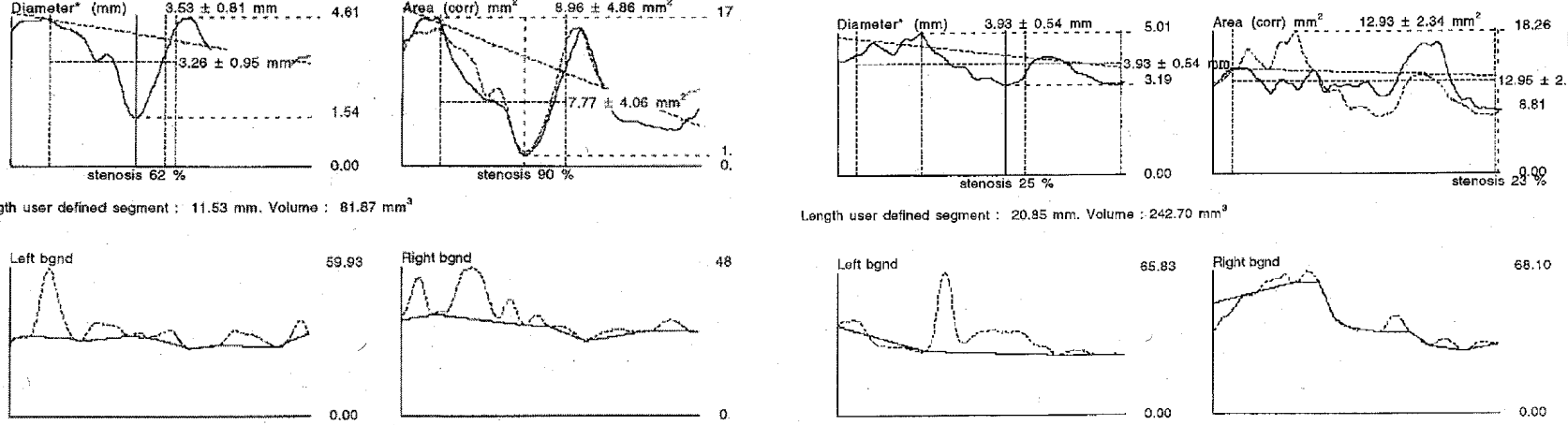

Lergth user defined segrment : $20.85 \mathrm{~mm}$. Volume $: 242.70 \mathrm{~mm}^{3}$
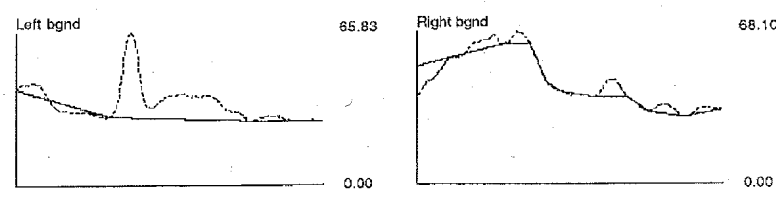

Fig. 2 CASS II によるQCA (coronary intervensionの前後)

QCAを意識し，冠動脈の形態を十分観察できる撮影 価ができることが大切である.

方向，撮影方法により，定量的指標と定性的指標の評

\title{
参考文献
}

1）延吉正清, 横井宏佳 : 冠動脈造影法により冠動脈狭窄を定 量化するには. 3rd Live Demonstration in Kokura，61-71， (1994).

2) 木村 風：PTCA後再狭窄. 治療学, 25(11), 1347-1350, (1991).

3) 延吉正清: コロナリーインターベンションの現況. 5th Live Demonstration in Kokura and Asian-Pacific Society of Intervention Cardiology Joint Conferece, 29-34, (1996).

4) Topol EJ: Textbook of Interventional Cardiology, 1052-1068. 5) 三和秋雄 : 心臓・冠状動脈の基礎解剖. 九州循環器撮影研 究会誌，2(1)，2-7，(1991).

6) Kuntz RE, Gibson M, Nobuyoshi M, et al.: Generalized model of restenosis after conventional balloon angioplasty, stenting, and directional atherectomy. J. Am. Coll. Cardiol., 21 (1), 1525, (1993).

\section{2. 心臓核医学検査のいま}

MCRESHCP

\section{1. はじめに}

初めて，核医学に応用された放射性物質はトレーサ としてであった。それは生体内を破壞することなく， 体外より高感度に検出できる手段が基本にある.今で 1997 年 6 月
は，生理的な機能や代謝を観察できるようになってき た，特に核医学検査の中で，心臓の検査部門を心臓核 医学と呼んでいる。この分野を支え発展させてきたの は，放射性医薬品の開発と撮影装置の進歩にある。今 
彴は免疫核医学や分子核医学と呼ばれる分野への発展 も予測されている。

\section{2. 心核医学桡壼の状況}

現在，核医学検查は全国で1 日に約7,000件行われ ている、この中で第 1 位の骨シンチ検查が 3 割，第 2 位に心蔵関連の検査が 2 割を占めている，近い将 来, 心缄検查が第 1 位になると予想されている。今ま での核医学の検査は，放射線科医師を主体に行われて きたが，十数年前より心葴の専門医が直接検査に立ち 会い，診断する時代になってきた，検査担当医師は， 運動あるいは薬物負荷の際に，心電図モニタや症状の 監視を要し，その病態との関連から，今では心葴専門 あるいは同等の知識をもつことが必要不可欠となって いる.

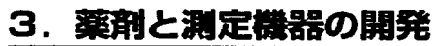

現在，日本全国にinvivo施設は1,184施設”ありこ の中でSPECT(single photon emission computed tomography)は1,493台2), PET (positron emission tomography)は35台が稼動している.これらPETで使 用される陽電子放出核種は，低原子番号に分布し，生 体構成元素でもあることから, 特に研究開発の薬剂と して利用されてきた。ここで開発に成功したPET薬剤 は，臨床で多用されているSPECT装置の薬剤へと試み られてきた。放射性医薬品の核種では， $\beta$ 線を放出 せず至適な $\gamma$ 線エネルギーを放出する ${ }^{99} \mathrm{~m} \mathrm{Tc},{ }^{123} \mathrm{I} の$ 標識化合物そして ${ }^{201} \mathrm{TI}$ がある。一方，新装置の話題 として, TCT (transmission computed tomography)が ある、今までは，投与されたRI分布を画像化するECT (emission computed tomography)のみであったが, 線 線源や面線源とシンチレーションカメラを組み合わせ て, $\gamma$ 線透過の断面画像を再構成する時代入突入して いる。この画像を吸収補正用の基礎データとして，よ り定量性のあるSPECT画像を目標にしている，特にコ ンピュータの発達(主メモリ容量の增大, 計算スピー ドの高速化)が，臨床㐫用を可能にしている。

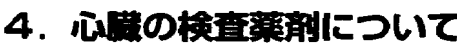

放射性核種は ${ }^{99 \mathrm{~m}} \mathrm{Tc} ，{ }^{123} \mathrm{I} ，{ }^{201} \mathrm{TI}$ が多用されている が， ${ }^{11}$ In ${ }^{18} \mathrm{~F}$ も用いられている，以下に放射性医薬品 の投与量とMIRD法3によよる吸収線量についても記載 する。

(1) ${ }^{201} \mathrm{TICl}$ (塩化タリウム)： ${ }^{201} \mathrm{TICl} は 1975$ 年に導入 された，静脈注入した ${ }^{201} \mathrm{TICl} は ，$ 局所心筋血流 分布に依存して心筋細胞に損取されるので，心 筋の血流分布を反映する。この ${ }^{201} \mathrm{~T} 1$ から生成さ れる水銀の特性X線は，エネルギーが低い(69
$80 \mathrm{keV})$ のために，人体組織で物理的に高い吸収 を受ける。また有効半減期も長いことから被曝 線量が多くなり，大量投与ができない（全身： $4 \mathrm{mGy} / 148 \mathrm{MBq})$

(2) ${ }^{99 m}$ Tc-PYP(ピロリン酸)：急性心筋梗塞の部位診 断をする。（全身：2.4mGy / 740MBq）

(3) ${ }^{99}$ Tc-HSA (ヒト血清アルブミン)：心プール製 剂であり心機能を評価する，他に同様の臨床目 的で99mTc-RBC (標識赤血球) も用いられる。（全 身 : $1.4 \mathrm{mGy} / 740 \mathrm{MBq}$ )

(4) ${ }^{99}$ Tc-MIBI : 心筋血流製剤として開発された が，腫瘍への集積も報告されている。 ${ }^{99 \mathrm{~m}} \mathrm{Tc心}$ 筋 血流製剂は， ${ }^{201}$ TIと比較して大量投与が可能と なり，情報量が多くなることから心電図同期心 筋SPECTにも有効である。（全身：1.5mGy／ $600 \mathrm{MBq}$ )

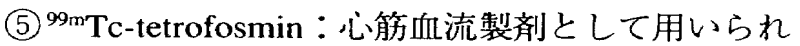
る，再分布を有しないので心筋虚血の診断に2 回投与が必要である。また， $\gamma$ 線エネルギーと 投与量の関係から，体格の大きい患者に対して 有利である。（全身：2.8mGy / 740MBq）

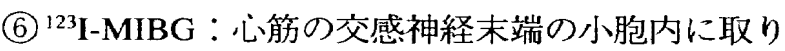
込まれることから, 心臟交感神経の機能を反映 するとされている。(心臓：1.2mGy / $111 \mathrm{MBq}$ )

(7) ${ }^{123}$ I-BMIPP：心筋脂肪酸代謝を反映する。（全 身: $1.5 \mathrm{mGy} / 148 \mathrm{MBq}$ )

(8) "'In-抗ミオシン抗体：心筋細胞の障害の程度を 陽性画像として描写する。

(9) ${ }^{18}$ F-FDG：心筋の糖代謝をみる.PET薬剂である が, 対向型 2 検出器のSPECT装置で画像化が試 みられている。

\section{5. 放射栍医蘶品の的作用について}

日本アイソトープ協会の医学・薬学部会放射性医薬 品安全性小委員会4で，毎年実施している副作用事例 の調査は，1996年に20回を迎えた。近年70数\%の回 答率を得ているので信頼性の高い日本のデータであ る。調査にまとめられている副作用(血管迷走神経反 応，発熱，アレルギ一反応，その他）は，RI投与 1,139,000件中で21件と，その発生率は0.0018\%であっ た、RI製剤による副作用は，X線撮影の造影剂に比較 すれば，非常に少ないのが特徴である。

\section{6. 多検出器時代について}

一つの検出器が当たり前だったシンチレーションカ メラシステムに 2 検出器 (対向)が, そして 4 検出器 (上下左右方向)，3 検出器 (正三角形方向) と, 多検出 器時代を迎えた。3検出器はおもにSPECT専用機とし 
て，2検出器はSPECTに加えて全身スキャンにも有効 な沉用機種として近年普及している。この対向 2 検出 器カメラヘッドの一方を90度回転させて，L字型に配 置し心蔵のSPECT検査ができる機種もある。この場 合，90度回転で180度のデータが収集できるため，検 査時間を短縮する利点がある。

\section{7. 是国技你}

心筋血流イメージングは ${ }^{201} \mathrm{TlCl}$ に始まり，当初はプ ラナー像 (正面像, 左前斜位像, 側面像)の撮影が主流 であった．現在では，ほとんどSPECT像による読影が 一般的になっている．SPECT画像は，X線CTやMRI と異なり，収集画像の大半の領域で断面を切り直すこ とができる．プラナ一像は 1 方向に投影された画像で あるが，SPECT像は臓器やバックグラウンドの重複を 分離し、コントラストの高い画像を提供している。 心 筋SPECT像の角度合わせは，左心室の長軸を基準にし て, 互いに直交する三つの断面(短軸面断層像, 長軸 面水平断層像，長軸面垂直断層像)を作成している.

(1)運動負荷，薬物負荷と再分布像

${ }^{201} \mathrm{TICl}$ を運動負荷最大時に投与すると, 運動 時の心筋血流量に比例して分布する。この運動 負荷法は心筋への高い取り込みと肝集積を低下 させ，虚血心筋の検出能を高めている，すなわ ち，運動時の心筋虚血部が欠損像として描写し 易くなる。つづいて, 約 3 時間後の安静時に再 度撮影すると，この虚血部分に再分布の有無を みることができる，血流低下部位に取り込まれ るか，それとも虚血のまま低カウントであるか を見分ける。また，この久損部位が安静時の ${ }^{201} \mathrm{TICl}$ 追加投与で取り込まれるか否かの検査も される (再静注法)。この再静注法は，心筋細胞 の活性化の指標であるviability (バイアビリティ) を評価することが可能であり，手術適用の判断 材料になる。また運動負荷が困難な患者には薬 物 (dipyridamole) 負荷によるRI投与が行われて いる.

(2) 2 核種収集心筋SPECT

${ }^{201} \mathrm{TICl}$ と ${ }^{99 \mathrm{~m}} \mathrm{Tc}$-ピロリン酸の 2 核種同時撮影が 行われ，急性心筋梗塞の有無と部位の検出に用

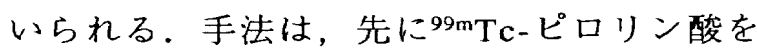
$740 \mathrm{MBq}$ 程度投与し, 約 3 時間後に ${ }^{201} \mathrm{TICl}$ を投 与して，20分後にこれらの 2 核種同時収集を行

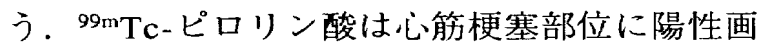
像として取り込まれ，一方 ${ }^{201} \mathrm{TICl}$ は正常心筋に は取り込まれるが, 梗塞部位は欠損し陰性画像 となる。これらは2核種の $\gamma$ 線エネルギー差を利

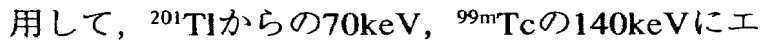

ネルギーウインドウを設定し，一度のSPECT収 集で別々の二つのファイルに保存する，両者は 幾何学的に同じ画像なので，同条件にて再構成 および角度合わせを行うと, ${ }^{99 \mathrm{~m}} \mathrm{Tc}$-ピロリン酸 と ${ }^{201} \mathrm{TICl}$ の画像が同じ位置で表示されることに なる．互いの $\gamma$ 線エネルギーによるクロストー クも問題になるが, この場合, 梗塞の集積部位 が互いに陽性と陰性画像に相反しているため, 影響は少なく，有病正診率の高い検査法であ る。

(3) bull's eye解析

bull's eyeは, 左室の心筋短軸断層像におい て，心尖部を円の内側に心基部を円の外側に配 置し，円形に展開した左室心筋のRIマップであ る. 雄牛の目に似ていることからこの名で呼ば れているが，要するに左心室軸に合わせた二次 元極座標表示で，心筋を含む短軸断層像の約 10 スライス分を一つの画像で認識できる.

(4) washout rate (WR: 洗い出し率)法

${ }^{201} \mathrm{TICl}$ による心筋SPECT像は，相対的な取り 込みを視覚判断で読影されている。したがっ て，3枝病変のすべての心筋で血流が低下する と見誤ることになる。しかし，WRを用いる と，その誤診を防ぐことができる．WRはbull's eyeの画像で作成され，負荷直後像 (early image) と䄪 3 時間後安静時像 (delayed image) を用い る。この早期像と遅延像の同部位で, 単位面積 当たりの摂取比を計算している．式は，WR= \{(early counts - delayed counts)/early counts\} $\times 100[\%]$ で求める. 正常は $40 \sim 50 \%$ 程度であ る. 3 枝病変ではWRが全体に低下する。

(5)平衡時マルチゲート法

この検査法は心缄のポンプとしての機能を駆 出率 (EF：ejection fraction[\%])として算出す る.RIを経静脈的に投与するだけの非侵襲的検 査であり，外来患者でも容易に施行できる，平 衡時法は，心プール製剤を投与して 2,3 分の時 間が経過すると心臓への入出量は等しくなり, 平衡状態になることに由来する。マルチゲート は心電図と同期させR波をトリガーとして，複 数の画像をコンピュータに入力する．収集とデ 一夕処理までを含め平衡時マルチゲート法と呼 ぶ.デー夕収集は，R波とR波の間を十数等分に 時間分割させ繰り返し収集するが，1 心拍では 情報量が少ないので，200～300心拍まで加算す る. 1 方向のデー夕収集につき 2〜5 分間を要す る. 体位はLAO 30度前後で右心室と左心室が中 隔を境に分離する角度に調整する。この 1 方向 
の撮影で得られた時間放射能曲線を容積曲線と 呼ぶ。ここで設定された関心領域(ROI)内の pixel数は左心室の面積を表しているが，計算に 用いているのは，このROI内のカウント総和な ので深さ方向の情報を含んでいる。この曲線の 高低差からEF值を算出する，最大カウント時を 拡張末期 (ED : end diastole), 最低カウント時を 収縮末期 (ES：end systole) と呼び，駆出率は， $\mathrm{EF}=\{(\mathrm{ED}-\mathrm{ES}) / \mathrm{ED}\} \times 100[\%]$ で計算される。

得られた心葴部画像に自動的に左室輪郭を ROI設定させ自動処理する。この手法はオペレ ー夕間の個人差がなく再現性に優れている，逆 に自動処理が円滑にできるようなデータ収集を 試みなければならない，同じ装置，同じ論理展 開による自動計算処理は，心機能の経過観察に 向いている．たとえば手術前後， $\beta$ 遮断薬の薬 物効果などを経時的に観察する手段に向いてい る.この時の出力結果で大切なことは, どのよ うな画像(位相画像, 振幅画像を含め)に, どん なROIの設定で容積曲線が表されたか，EF值を 含む各パラメータを同時表示し，あとで客観的 に評価できるデータを同時報告書とすることで ある。

最近， ${ }^{99 \mathrm{~m}} \mathrm{Tc}$ 製剤を用いた心電図同期SPECT法 からEFを算出できるようになった。これはコン ピュータの高速性が，実用化を現実のものにさ せて抢り，心筋部に取り込まれた ${ }^{99 m} \mathrm{Tc}$ c心電同
期しSPECT収集をする。すなわち三次元の SPECT像と, 心電同期された時間軸の四次元の データを取り扱う。この各断面ごとの心笳部に ROIを設定し, 心内腔の総voxel数の時間変化率 からEF値を算出する。

\section{8. 模直踶用について}

他の検査と比較する場合, その検査費用も重要な因 子と考え, 当施設での診療報酬を揭示する. ${ }^{201} \mathrm{TICl}$ 心 筋SPECT検査；85,000円， ${ }^{99 m}$ Tc-tetrofosmin心筋 SPECT検查；82,000円， ${ }^{99^{m}}$ Tc-MIBI心筋SPECT検査； 85,000円， ${ }^{123}$ I-BMIPP心筋SPECT検査；58,000円，心 プール心電図同期駆出率測定；51,000円である.以上 は10割負担の価格だが, コストパフォーマンスを考慮 しても決して安価な検査ではない。

\section{9. おわりに}

核医学画像は他のモダリテイの画像と比較すると解 像力が低く，解剖学的な情報が少ないことは事実であ る.しかし，心缄の定量解析や機能解析は核医学の大 きな特徴であり，今後も長所として活かさねばならな い. また最近の核医学デー夕処理装置は高性能のワー クステーションを採用しているので通信機能が容易に 搭載できる。近い将来, 他のモダリティとの通信ネッ トワークが充実すれば，レポーティングシステムや核 医学画像の迅速なデー夕供給も現実化され，有機的な 臨床応用が期待される.
1)放射性医薬品流通統計：Isotope News 506(7)，32-39, (1996).

2)新医療: No.255 (3), 105-125, (1996).

3) MIRD (Medical Internal Radiation Dose) : The Society of
Nuclear Medicine, pamphlet no. $1 \sim 14$.

4)放射性医薬品副作用事例調查報告 第17報：核医学, 33 (6), 675-686, (1996)

\section{3. 心カテーテル検査から得られる情報・ 心エコ一図検查から得られる情報}

\section{UCFKSトCF

\section{1. はじめに}

超音波検査により得られる情報と心カテーテル検査 により得られる情報の差を知るためには，超音波画像 の性質やドプラー法の原理を知ることが必要である.

\section{1-1 超音波の性質}

超音波法では，(1)人体内における音速が一定で(搨 氏 $37^{\circ}$ で $\left.1530 \mathrm{~m} / \mathrm{sec}\right)$, (2) 超音波は体内を直進し, 音響 インピーダンスの異なる境界面で反射するということ が前提となっている。これらの前提が成立しなければ
形態が不正確になったり，存在しない画像が得られる 場合がある(アーチファクト).

超音波は空気や骨を透過することはできない。した がって，超音波を入射し目標に到達させ得る部位（心 荗空)や観察し得る範囲には制限がある。

\section{1-2断層心エコー図の特徴}

心血管造影法により得られる画像は投影像であり， 超音波法により得られる画像は断層像である。

超音波画像は，送信された超音波が，対象で反射さ 